\title{
Przestrzenie aktywności nauczyciela akademickiego i studenta w świetle dydaktyki zaangażowanej
}

\author{
Spaces of Activity of the Academic Teacher and \\ Student in Light of Engaged Didactics
}

\begin{abstract}
ABSTRAKT
Celem przedstawionego opracowania jest ukazanie specyfiki integracji akływności nauczyciela akademickiego i studentów pedagogiki/przyszłych nauczycieli. Punktem odniesienia przedstawionych analiz jest dydakłyka zaangażowana, u podstaw której znajdują się integracja sfery poznawczej/intelektualnej i aksjologicznej z osobowościowq, zmiana prorozwojowa w perspektywie podmiotowości, autonomii twórczości podmiotów kształcenia akademickiego, zwłaszcza studentów w perspektywie integracji.

W dydaktyce zaangażowanej kluczowym pojęciem jest zaangażowanie, które jest rozumiane jako pewien typ praktyki dyskursu badawczego uwzględniającego przede wszystkim potrzeby emancypacyine konkretnych grup osób. Badacze uczestniczqcy w tym dyskursie angażuja się w projekty, których celem jest zmiana społeczna, a nie tylko poprawa położenia defaworyzowanych podmiotów. Natomiast istotq i warunkami brzegowymi tej praktyki jest poczucie podmiotowości zarówno samych badaczy, jak i uczestników sytuacji
\end{abstract}

SLOWA KLUCZOWE zaangażowanie, dydaktyka zaangażowana, osoba, aktywność nauczyciela akademickiego, aktywność studentów

\section{KEYWORDS}

involvement, engaged didactics, person, academic teacher activity, student activity

SPI Vol. 23, 2020/2

ISSN 2450-5358

e-ISSN 2450-5366 DOI: 10.12775/SPI.2020.2.006

Nadestano: 3.11.2019 Zaakceptowano: 19.05.2020

Artykuły i rozprawy 
społecznych, kłórzy w sposób dobrowolny i z poczuciem satysfakcji uczestnicza w tego rodzaju działaniach.

"Dydaktyka zaangażowana" określana jest jako typ podmiotowych działań dydaktycznych nauczyciela akademickiego i studentów, o charakterze zmian prorozwojowych budowanych dzięki komunikacji interpersonalnej, wzajemnemu zaufaniu, służbie, wyzwalajacych twórcza aktywność. Podstawę tych działań stanowi integracja zdobywanej przez studenta wiedzy, orientowana na integralny rozwój osoby w jej wymiarze jednostkowym i społecznym. Perspektywa działań nauczyciela akademickiego i studentów jest integralny rozwój ucznia jako nadrzędnego celu szkoły i optymalizacja warunków jego realizacji.

\section{ABSTRACT}

The aim of the article is to describe the integration of the activity of an academic teacher and pedagogy students/future teachers. The reference point for the analysis is engaged didactics, which is based on the integration of the cognitive/intellectual and axiological spheres with personality and developmental change from the perspective of subjectivity and autonomy of creativity within academic education, especially of students in terms of integration.

In engaged didactics, the key concept is commitment, which is understood as a certain type of research discourse practice that primarily takes into account the emancipatory needs of specific groups of people. Researchers participating in this discourse engage themselves in projects aimed at social change, and not only at improvement of the position of the disadvantaged. On the other hand, the essence and boundary conditions of this practice is the sense of subjectivity of both the researchers and participants of social situations who voluntarily and with a sense of satisfaction participate in this type of activity.

"Engaged didactics" is defined as a group of subjective didactic activities of an academic teacher and students that consists of developmental changes built on interpersonal communication, mutual trust, and service which trigger creative activity. The basis of these activities is the integration of knowledge acquired by the student, focused on the integral development of the person individually and socially. The perspective of the academic teacher and students is the integral development of the student as the primary goal of the school and the optimization of the conditions for its implementation. 


\section{Dydaktyka zaangażowana - zarys zagadnienia}

Dydaktyka ogólnie definiowana jest jako

[...] nauka o kształceniu i samokształceniu (samodoskonaleniu), przy czym kształcenie obejmuje zarówno sferę poznawczą, intelektualną, jak i sferę osobowościową, związaną głównie z kształtowaniem postaw uczniów i systemem wartości. Jako jedna $\mathrm{z}$ dyscyplin pedagogicznych obok pedagogiki ogólnej, teorii wychowania, historii wychowania - należy do podstawowych nauk pedagogicznych, służy także wychowaniu, czyli wspieraniu rozwoju osobowości uczniów (Bereźnicki 2001: 12).

Definicja ta może być po części wykorzystana dla określenia dydaktyki zaangażowanej kształcenia przyszłych nauczycieli. Na uwage w tym względzie zasługuje integracja sfery poznawczej, intelektualnej i aksjologicznej z osobowościową. Nie ujmuje ona jednak problematyki zmiany prorozwojowej: osobowej i społecznej w perspektywie podmiotowości, autonomii, twórczości podmiotów kształcenia akademickiego, zwłaszcza studentów w perspektywie integralności.

„Rdzeniem” dydaktyki zaangażowanej jest zagadnienie integralnego rozwoju osoby studenta i ucznia jako nadrzędnego celu szkoły. Cel ten wyznacza dalszą perspektywę pełnych zmian rozwojowych odnoszących się do studenta i nauczyciela akademickiego, rozwoju szkoły oraz doskonalenia procesu dydaktycznego i badawczego nauczyciela akademickiego zintegrowanego z procesem badawczym i projektowym studentów. Punktem wyjścia w dydaktyce zaangażowanej jest wizja zmiany prorozwojowej studentów - przyszłych nauczycieli $-\mathrm{w}$ świetle integralnego rozwoju oraz wizja zmiany funkcjonowania szkoły i wdrażania na bazie jedności: paradygmatów, teorii dydaktycznych oraz praktyki: myślenia i działania pedagogicznego w wymiarze wychowawczo-dydaktycznym - teoretyzowania i badania (Červinková, Gołębniak 2010: XV). W wizji zmian skupiają się jak w soczewce tożsamość nauczyciela i studenta.

W dydaktyce zaangażowanej dochodzi do integracji teorii z praktyką dydaktyczną, co wyraża się w aktywności dydaktycznej, wychowawczej i badawczej nauczyciela akademickiego, aktywności współdydaktycznej i samokształceniowej studentów na bazie procesu badawczego oraz ich projektowej aktywności. Strukturę tę ilustruje poniższy schemat. 
Schemat 1. Proces integracii teorii z praktykq dydaktycznq dokonujq̨cy się $w$ dydaktyce zaangażowanej

\begin{tabular}{|c|c|}
\hline $\begin{array}{l}\text { Aktywność nauczyciela } \\
\text { akademickiego } \\
\text { - dydaktyczna } \\
\text { - badawcza } \\
\text { - wychowawcza }\end{array}$ & $\begin{array}{l}\quad \text { Aktywność studenta } \\
\text { - współdydaktyczna } \\
\text { - samokształceniowa } \\
\text { - badawcza } \\
\text { - samowychowawcza/ } \\
\text { formacyjna }\end{array}$ \\
\hline
\end{tabular}

Źródło: Opracowanie własne.

Powyżej wskazane aktywności nauczyciela akademickiego i studentów realizowane są na fundamentach dyskursu badawczego, w którym na pierwszym miejscu usytuowane są potrzeby twórcze tych dwóch podmiotów. W teoretycznych poszukiwaniach i praktycznych rozwiązaniach dydaktyki akademickiej w kształceniu pedagogów o specjalności nauczycielskiej przyjęto następujące założenia: 1) student powinien mieć szansę zdobycia wiedzy o holistycznym wymiarze - wiedzy zintegrowanej, która obejmuje wiedzę z różnych dziedzin i dyscyplin, $w$ tym dyscyplin specjalistycznych; 2) w uczelni młody człowiek/student powinien mieć stworzone sprzyjające warunki do rozwoju integralnego, dynamicznego, poszczególnych sfer życia i funkcjonowania człowieka, integrowania ich ze sobą oraz do badań w tym zakresie; 3) okres studiów dla młodego człowieka jest czasem rozwoju i dążenia do pełniejszej odpowiedzi na pytania: „Kim jestem i jaki jestem", wchodzenia w relacje z innymi, kształtowania stosunków międzyludzkich $\mathrm{w}$ aspekcie rozumienia innych i wzrostu świadomości poszukiwania płaszczyzn samorealizacji, samostanowienia, potwierdzania siebie $\mathrm{w}$ procesie nabywania samodzielności sądów i autonomii w podejmowaniu decyzji; 4) uniwersytet powinien być kuźnią kadr oraz dojrzałych i odpowiedzialnych pomysłów. Indywidualizacja w kształceniu studentów, u podstaw której prowadzony jest dialog między studentami a nauczycielem akademickim, jest w stanie ukształtować te dwa podmioty jako ludzi wrażliwych, wolnych w dążeniu do prawdy, a jednocześnie odpowiedzialnych za siebie i wypełnianie swojej misji zawodowej.

Charakterystyczne dla tak ujętej dydaktyki zaangażowanej jest eksponowanie w procesie kształcenia akademickiego i wychowawczo-dydaktycznego osoby ludzkiej, rozumianej jako cielesno-duchowa 
jedność. Osoba studenta i osoba ucznia stanowią punkt wyjścia i dojścia w pracy pedagogicznej nauczyciela akademickiego. Można więc powiedzieć, że cechą tej pracy jest „osobocentryzm”. Rozwój przymiotów osoby ludzkiej (godność, rozumność, mądrość, wolność, odpowiedzialność, zdolność do miłości, twórczości, transcendencji) staje się punktem wyjścia i nadrzędnym celem procesu kształcenia akademickiego studenta - przyszłego nauczyciela, który w przyszłości będzie wspomagał osobę ucznia w osiąganiu pełni człowieczeństwa.

W kształceniu rozwoju studenta ważne jest otwarcie na wartości. Pełnią one w życiu człowieka wiele funkcji, m.in.: poznawczą, motywacyjną, informacyjną, kulturotwórczą. $Z$ uwagi na wielostronność znaczenia wartości istnieje potrzeba solidnego przygotowania studentów do działań pedagogicznych opartych na mocnej podstawie aksjologicznej. Chodzi głównie o to, by wyposażyć studenta w kompetencje rozpoznawania wartości, budzić wrażliwość aksjologiczną, motywować do wyboru wartości, wnikać w ich fenomen przez zdobywanie wiedzy, budować właściwe struktury preferowanych i urzeczywistnianych wartości, animować innych do podjęcia tego procesu. Celem dydaktyki zaangażowanej nie jest tylko przygotowanie do zawodu nauczyciela. Jej ostateczny cel stanowi pełny rozwój intelektualny, społeczny i duchowy studenta, prowadzący do odpowiedzialnego i twórczego działania pedagogicznego, stwarzającego wielostronne szanse integralnego rozwoju zarówno studenta, jak i wykładowcy akademickiego, a w przyszłości ucznia, nauczyciela i kultury samej szkoły.

W powyższym kontekście jawi się zadanie doprowadzania do integracji osobowości studenta, rozwoju jego dojrzałości, aby w przyszłości mógł on być twórczym nauczycielem, który będzie potrafił się przyczyniać do rozwoju sfery intelektualnej, społeczno-moralnej, kulturowej, duchowej i religijnej powierzonych mu uczniów. Zakres i charakter zmian prorozwojowych zorientowanych na studenta, nauczyciela akademickiego, ucznia i szkoły realizuje się dzięki komunikacji interpersonalnej między studentem i nauczycielem, dialogowi, dyskusjom podejmowanym w perspektywie twórczej wizji przyszłych działań pedagogicznych. W dydaktyce zaangażowanej istotną funkcję pełni dialog, który wyznacza humanistyczne, osobowe relacje między podmiotami kształcenia, wyrażające się w szczerości, otwartości, szacunku, zrozumieniu, trosce o drugiego człowieka, 
odkrywaniu potencjału pedagogicznych możliwości. Tak rozumianą dydaktykę konstytuują:

- osoba i jej przymioty,

- tożsamość nauczyciela akademickiego i studenta,

- kultura szkoły,

- zmiana prorozwojowa i kierowanie tą zmianą,

- doświadczenie poznawcze/refleksja pedagogiczna,

- działania projektowe,

- wartościujące ocenianie ${ }^{1}$.

\section{Wybrane zakresy aktywności nauczyciela akademickiego i studenta}

Poniżej przedstawiono zakresy aktywności nauczyciela akademickiego i studenta w trzech obszarach: 1) przymioty osoby ludzkiej; 2) tożsamość człowieka; 3) kultura szkoły.

\section{Osoba i jej przymioty}

Odpowiedź na pytanie: „Kim jest człowiek” stanowi źródło celu, istoty i przebiegu procesów wychowawczych. Według Franciszka Adamskiego:

Personalistyczna odpowiedź podkreśla dwuwymiarowość egzystencji człowieka - osoby posiadającej wartość in se, to znaczy wartość ontologiczną. Zgodnie z tym stanowiskiem każdy człowiek: jest osobą - także zanim jest w stanie uzyskać pełnię swej autonomii (tę wartość posiada od momentu poczęcia); posiada swą godność i wartość przysługującą mu z natury; jest wartością najwyższą, bezwzględną - w świecie bytów stworzonych jest jedyną rzeczywistością posiadającą wartość per se; będąc wartością per se, osoba ma własny cel, jakim jest doskonalenie się w swym istnieniu - nie może być traktowana jako środek do celu innego człowieka lub społeczeństwa. Jej doskonalenie oznacza zwrócenie się ku dobru i osiąganie coraz wyższego stopnia uczestniczenia w nim. To skierowanie ku dobru stanowi szczególne wyzwanie dla osoby: poprzez samodoskonalenie się, upodabnianie się do pełni Dobra, Prawdy i Piękna. Dążenie do doskonałości jest obowiązkiem moralnym osoby wynikającym z jej wnętrza. Jest też wynikiem świadomości potrzeby dążenia

1 Zob. Szerzej na ten temat: Chałas (2019: 69-80, 94-120), skąd zaczerpnięto ww. przewodnie myśli. 
do doskonałego trwania, przekraczającego barierę czasu i przestrzeni (Adamski 2005: 13-14).

W kontekście dydaktyki zaangażowanej przymioty osoby ludzkiej: godność, rozumność, mądrość, wolność, zdolność do miłości, zdolność do transcendencji warunkują przestrzenie aktywności nauczyciela akademickiego i studentów oraz szczegółowe działania, postawy, urzeczywistniane wartości. Poniżej w skrótowej formie ukazane zostanie powyższe zagadnienie.

W kontekście dydaktyki zaangażowanej przymioty osoby ludzkiej stanowią ważne cele warunkujące proces dydaktyczny kształcenia studentów. Godność osobowa (dana) człowiekowi zobowiązuje nauczyciela akademickiego i studenta do poszanowania własnej godności i godności drugiego człowieka. Rozumność i mądrość warunkują poznawanie i wybór prawdy oraz życie prawdą. Najpierw prawdy o sobie, o tym, „kim jestem i jaki jestem”, w której swe znaczące miejsce znajduje prawda o przemianie własnych predyspozycji i kompetencji nauczycielskich. Ważną kwestią jest rozeznanie dobra i zła. W przypadku nauczyciela akademickiego to rozeznanie kierowane jest na dobór i układ kształcenia, sposoby pracy ze studentami, dydaktyczną wartość dodaną w aspekcie optymalizacji szans integralnego rozwoju studentów. Istotnego znaczenia nabiera orientacja na dobro ukierunkowujące własne badania naukowe. Rozumność i mądrość kierują studenta na wartość wiedzy akademickiej postrzeganej w kategoriach dobra. Zobowiązują do pracy nad własnym rozwojem, do nabywania kompetencji nauczycielskich oraz ukierunkowania na dobro, w urzeczywistnianiu którego będzie on w przyszłości wspomagał swoich uczniów.

Wolność warunkuje autonomię, która jest rdzeniem „dydaktyki zaangażowanej”. Przejawia się ona w autonomicznych działaniach nauczyciela akademickiego i studenta, wyzwalaniu się z utartych schematów postępowania, w niezgodzie na aktualny stan rzeczy i zjawisk; orientuje ku nowatorskim rozwiązaniom tu i teraz oraz w przyszłości w perspektywie dobra rozwojowego. Zdolność do twórczości nadaje działaniom dydaktycznym (współdziałaniom dydaktycznym) nowego blasku w treści i formie. Wzmacnia indywidualność i kreuje nowe jej kształty. 
Odpowiedzialność zobowiązuje nauczyciela akademickiego do pracy nad sobą, rozwoju naukowego, budowania procesu dydaktycznego zorientowanego na rozwój u studentów kompetencji nauczycielskich, miłości wychowawczej, potrzeby doskonalenia siebie w perspektywie integralnego rozwoju, zaś studenta - do pracy nad sobą w aspekcie zdobywania wiedzy, rozwoju swoich predyspozycji, umiejętności projektowania wizji przyszłej pracy zawodowej, w której nowatorstwo pedagogiczne znajdzie swe znaczące miejsce. Ważną kwestią w tym względzie jest budowanie autorytetu pedagogicznego, wzoru osobowego godnego naśladowania, jako podstawowego warunku zabezpieczającego przed defaworyzowaniem, marginalizowaniem, przedmiotowym traktowaniem innych $\mathrm{w}$ pracy zawodowej. Miłość warunkuje relacje między nauczycielem akademickim a studentem nacechowane przyjaźnią, zaufaniem, poszanowaniem, troską, wzajemną służbą i odpowiedzialnością, w których to relacjach swe znaczące miejsce zajmuje poszanowanie godności.

Zdolność do transcendencji stanowi istotny warunek sukcesu nauczyciela akademickiego i studentów zarówno w procesie ich kształcenia akademickiego, jak i w przyszłej pracy nauczycielskiej. Przez transcendencję wyjaśnia się sens i piękno pracy pedagogicznej. Ten fakt znaczenia transcendencji w życiu i funkcjonowaniu człowieka podkreśla Mieczysław A. Krąpiec:

Ludzka osoba jest osobowością potencjalną, a więc taką, która poprzez akty doskonali się, buduje i spełnia, czyli dochodzi do pełni. We wszystkich tych aktach potrzebna jest ludzkiej osobie materia; ale cele takiego „uzupełnienia się" są daleko pozamaterialne, a wyznaczone charakterem i prawami materii. Cele bowiem osoby są wewnętrzne, osobowe: wzbogacenie poznania, wzbogacenie miłości, uzyskanie wyższego stanu wolności w stosunku do wszelkich determinantów - czy to wewnętrznych, czy zewnętrznych. Przez taki typ wewnętrznego ubogacenia się człowiek transcenduje przyrodę, chociaż jest w niej obecny poprzez swe życiowe akty, zwłaszcza akty psychiczne. Dokonuje autofirmacji i rozwoju głównie poprzez wykształcenie w sobie sposobu bytowania „dla-osoby-drugiej”. Ostatecznie zaś aktualizuje swą osobową potencjalność poprzez moment śmierci (Krąpiec 2005: 40).

Przestrzenie aktywności nauczyciela akademickiego i studenta przedstawia tabela nr 1. 
Tabela 1. Przestrzenie aktywności nauczyciela akademickiego i studenta w aspekcie przymiotów osoby ludzkiej

\begin{tabular}{|c|c|c|}
\hline Przymioty osoby & Nauczyciel akademicki & Student \\
\hline Godność osoby & $\begin{array}{l}\text { - Poszanowanie siebie i studenta/ } \\
\text { każdego człowieka. }\end{array}$ & $\begin{array}{l}\text { - Poszanowanie siebie i nauczy- } \\
\text { ciela akademickiego/każdego } \\
\text { człowieka. } \\
\text { - Projektowanie działań pedago- } \\
\text { gicznych, w których urzeczywist- } \\
\text { niana będzie wartość godności. }\end{array}$ \\
\hline Godność osobowościowa & $\begin{array}{l}\text { Podejmowanie działań moralnie } \\
\text { wartościowych. } \\
\text { - Urzeczywistnianie wartości } \\
\text { moralnych. }\end{array}$ & $\begin{array}{l}\text { - Podejmowanie działań moralnie } \\
\text { wartościowych. } \\
\text { - Urzeczywistnianie wartości } \\
\text { moralnych. }\end{array}$ \\
\hline Rozumność/mq̨drość & $\begin{array}{l}\text { - Poszukiwanie prawdy, od- } \\
\text { krywanie prawdy, głoszenie } \\
\text { prawdy. } \\
\text { - Rozumienie dobra i zła. } \\
\text { - Urzeczywistnianie wartości } \\
\text { dobra w: } \\
\text { - badaniach naukowych, } \\
\text { - procesie kształcenia } \\
\text { studentów. }\end{array}$ & $\begin{array}{l}\text { - Poszukiwanie prawdy, od- } \\
\text { krywanie prawdy, głoszenie } \\
\text { prawdy. } \\
\text { - Rozumienie dobra i zła. } \\
\text { - Urzeczywistnianie wartości } \\
\text { dobra w: } \\
\text { - zaangażowaniu w pracę } \\
\text { samokształceniowa } \\
\text { - zaangażowaniu we własne } \\
\text { badania, projekty rozwoju } \\
\text { szkoły, } \\
\text { - zaangażowaniu } \\
\text { w samowychowanie/ } \\
\text { formacie, } \\
\text { - projektowaniu działań } \\
\text { pedagogicznych, w których } \\
\text { urzeczywistniana będzie } \\
\text { mqdrość. }\end{array}$ \\
\hline Wolność & $\begin{array}{l}\text { Podejmowanie autonomicznych } \\
\text { działań w procesie badawczym } \\
\text { i dydaktycznym. } \\
\text { Wdrażanie innowacji i działal- } \\
\text { ności eksperymentalnej. }\end{array}$ & $\begin{array}{l}\text { - Opracowanie i realizacja } \\
\text { koncepcji indywidualnego } \\
\text { kształcenia i toku nauczania. } \\
\text { Projektowanie autorskich roz- } \\
\text { wiqzań pedagogicznych. }\end{array}$ \\
\hline Odpowiedzialność & $\begin{array}{l}\text { - Podejmowanie pracy nad sobq. } \\
\text { - Podejmowanie działalności } \\
\text { naukowej w perspektywie } \\
\text { dynamicznego rozwoju. } \\
\text { - Budowanie procesu dydaktycz- } \\
\text { nego w perspektywie dosko- } \\
\text { nałości, twórczości profesjo- } \\
\text { nalizacji pracy nauczycielskiej } \\
\text { studentów. } \\
\text { - Budowanie własnego autorytetu } \\
\text { jako wzoru osobowego godne- } \\
\text { go naśladowania. }\end{array}$ & $\begin{array}{l}\text { - Podejmowanie pracy nad sobq } \\
\text { w perspektywie twórczego } \\
\text { nauczyciela i wzoru osobowego } \\
\text { godnego naśladowania. } \\
\text { - Projektowanie działań pedago- } \\
\text { gicznych, w których urzeczy- } \\
\text { wistniana będzie wartość } \\
\text { odpowiedzialności. }\end{array}$ \\
\hline
\end{tabular}




\begin{tabular}{|c|c|c|}
\hline Przymioty osoby & Nauczyciel akademicki & Student \\
\hline Miłość & $\begin{array}{l}\text { - Budowanie relacji interper- } \\
\text { sonalnych ze studentami, } \\
\text { w których urzeczywistniane } \\
\text { będa: przyjaźń, poszanowanie, } \\
\text { zaufanie, troska, dar z siebie, } \\
\text { odpowiedzialność. } \\
\text { - Projektowanie działań pedago- } \\
\text { gicznych, w których urzeczywist- } \\
\text { niana będzie wartość miłości. }\end{array}$ & $\begin{array}{l}\text { - Budowanie relacji interper- } \\
\text { sonalnych z nauczycielem } \\
\text { akademickim, w których } \\
\text { urzeczywistniane będa: przy- } \\
\text { jaźń, poszanowanie, zaufanie, } \\
\text { godność, włqczanie się w pro- } \\
\text { ces dydaktyczny i badawczy, } \\
\text { odpowiedzialność. }\end{array}$ \\
\hline Transcendencja & $\begin{array}{l}\text { Wewnętrzne ubogacenie } \\
\text { w pełnieniu funkcji nauczyciela } \\
\text { akademickiego. } \\
\text { - Stawianie sobie ambitnych } \\
\text { celów i zadań oraz zaangażo- } \\
\text { wanie się w ich realizację. } \\
\text { - Przekraczanie siebie. }\end{array}$ & $\begin{array}{l}\text { - Wewnętrzne ubogacenie się } \\
\text { w pełnieniu roli studenta. } \\
\text { - Stawianie sobie ambitnych } \\
\text { celów w procesie studiowania } \\
\text { i w perspektywie przyszłej } \\
\text { pracy zawodowej. }\end{array}$ \\
\hline
\end{tabular}

Źródło: Opracowanie własne.

\section{Tożsamość}

Kreowanie tożsamości studentów, w tym tożsamości zawodowej w perspektywie przyszłości, jest ważnym zadaniem nauczyciela akademickiego, ponieważ - jak zauważa Agnieszka Cybal-Michalska - „[...] problematyka tożsamości krystalizuje problem trajektorii jednostkowych losów w karierze i konstruowania tożsamości zawodowej podmiotów" (Cybal-Michalska 2018: 126). Na uwagę w tym względzie zasługuje Lecha Witkowskiego pedagogiczna implikacja teorii tożsamości Jürgena Habermasa. Stanowi ona perspektywę działań dydaktyki zaangażowanej. Punktem wyjścia teoretycznych analiz jest odpowiedź na pytanie o to,

[...] co decyduje, iż zmienny (fizycznie, psychicznie, społecznie) człowiek czy pewna całość społeczna jest ciągle tym samym bytem, trwającym integralnie i postrzeganym jako taki bynajmniej nie $\mathrm{z}$ racji bezpośrednio rozpoznawalnej powłoki cielesnej czy innych trywialnych wyróżników identyfikacyjnych (np. imienia, dokumentów). Pytanie więc to w istocie zmierza do ukazania płaszczyzny, w której rozstrzyga się jakość i trwałość szczególnego procesu kwalifikacji człowieka jako bytu społecznego (Witkowski 2010: 111). 
Tę płaszczyznę tworzy trójzakresowy, poziomy profil tożsamości składający się z trzech zakresów: kompetencja $\rightarrow$ koncepcja $\rightarrow$ kondycja (Witkowski 2010: 143).

Powyższa triada wyznacza trójzakresową bazę epistemologiczną pojęcia tożsamości: poczucia tożsamości, kondycji życia, tożsamości umiejscowień, koncepcji o świecie, tożsamości w zakresie kompetencji do działania (Witkowski 2010: 146).

W kontekście tematu niniejszego opracowania na szczególną uwage zasługuje kompetencja do działania, stanowi bowiem ona istotny cel kształcenia studentów. Ważną kwestią jest tutaj poziom tożsamości, określany jako poziom postkonwencjonalny. Charakteryzuje się on postrzeganiem świata jako wciąż zadanego do stworzenia, a więc w kategoriach zmiany, dokonywania wyborów, krytycznej oceny, tworzenia nowych wartości.

Poziom tożsamości postkonwencjonalnej konstytuują: otwartość na zmiany o charakterze nowatorskim, kreatywność, zdolność do niezgody, sprzeciw wobec zastanej rzeczywistości, wejście w konflikt $\mathrm{z}$ zastanym układem, projektowanie alternatywnych rozwiązań, podmiotowe zaangażowanie w zmianę na bazie własnych projektów, urzeczywistnianie wartości, budowanie i urzeczywistnianie kontekstu aksjologicznego. Te zadania stoją także przed studentami - przyszłymi nauczycielami. Powyżej wskazane komponenty stanowią pożądane cechy nauczyciela jako refleksyjnego praktyka, nowatora, animatora życia społeczno-kulturowego, zaangażowanego badacza procesów edukacyjnych.

Powyższy kontekst pozwala określić zakres aktywności nauczyciela akademickiego i studenta. Tę strukturę przedstawia poniższa tabela. 
Tabela 2. Zakres aktywności nauczyciela akademickiego i studenta dla postkonwencjonalnego poziomu tożsamości

\begin{tabular}{|c|c|c|}
\hline Przestrzeń & Nauczyciel akademicki & Student \\
\hline $\begin{array}{l}\text { Tożsamość - kompetencja do } \\
\text { działania: poziom postkonwen- } \\
\text { cjonalny }\end{array}$ & $\begin{array}{l}\text { - Poszukiwanie nowych obsza- } \\
\text { rów badawczych. } \\
\text { - Projektowanie nowych obsza- } \\
\text { rów badawczych. } \\
\text { - Projektowanie nowych progra- } \\
\text { mów kształcenia. } \\
\text { - Projektowanie i wdrażanie } \\
\text { innowacji dydaktycznych. } \\
\text { - Projektowanie i wdrażanie } \\
\text { programów integracji procesu } \\
\text { dydaktycznego z badawczym. } \\
\text { - Projektowanie i wdraża- } \\
\text { nie programów właczania } \\
\text { studentów we własny proces } \\
\text { badawczy. } \\
\text { - Animacja studentów do dzia- } \\
\text { łalności naukowej. }\end{array}$ & $\begin{array}{l}\text { - Właczanie się w proces } \\
\text { badawczy nauczyciela } \\
\text { akademickiego. } \\
\text { - Projektowanie własnych badań } \\
\text { naukowych o ambitnych } \\
\text { celach. } \\
\text { - Poszukiwanie innowacyi- } \\
\text { nych sposobów pracy } \\
\text { samokształceniowej. } \\
\text { - Projektowanie innowacyinych } \\
\text { programów dydaktycznych } \\
\text { i wychowawczych opartych } \\
\text { na mocnych podstawach } \\
\text { aksjologicznych. }\end{array}$ \\
\hline
\end{tabular}

Źródło: Opracowanie własne.

U podstaw przedstawionego spektrum aktywności znajduje się zaangażowanie nauczyciela i studenta. Zaangażowanie jednostkowe i społeczne wyraża się w postawie zaangażowania warunkującego budowanie dobra jednostkowego i grupowego, która uzdalnia do działań autonomicznych i twórczych.

Chodzi głównie o zaangażowanie na poziomie postkonwencjolanym, które uwarunkowane jest działaniem zmierzającym do zlikwidowania przeżycia niedoboru stopnia urzeczywistnianych wartości. Czynnikami wyzwalającymi zaangażowanie na tym poziomie są: niezgoda na ograniczenia podmiotowości, niezgoda na dotychczasowe wzory zachowań oraz odwaga.

\section{Kultura szkoły}

W kontekście kształcenia przyszłych nauczycieli swego rodzaju ośrodkami zainteresowań w procesie kształcenia akademickiego i badań naukowych są szkoła, jej funkcje, jej kultura.

Gdy mówimy o kulturze szkoły, mamy na myśli kulturę szkoły jako organizacji. Kultura organizacji, według Edgara Scheina, to 
[...] wzorzec podstawowych założeń - wymyślonych, rozwiniętych lub odkrytych przez daną grupę w trakcie uczenia się, jak radzić sobie z zadaniami zewnętrznej adaptacji i wewnętrznej integracji - sprawdzanych w działaniu na tyle, by uznać je za odpowiednie, a tym samym przekazywanych nowym członkom jako właściwy sposób postrzegania myślenia i odczuwania w przypadku napotkania owych zadań (Schein 1990, za: Tuohy 2002).

W powyższym kontekście kultura szkoły rozwija się na podłożu znaczeń podzielanych przez nauczycieli. Znaczenia te mają swoje zakorzenienie w historii i celach nauczycielskiej pracy. Rozwój ten warunkują dwa czynniki: 1) wolność swobodnych wyborów spośród licznych możliwości, zwłaszcza w zakresie celów, treści programowych, koncepcji metodycznych w perspektywie rozwoju nauczyciela, uczniów, szkoły; 2) sposoby reagowania na czynniki zewnętrzne, niezależne okoliczności (Schein 1990, za: Tuohy 2002). Jak podkreśla David Tuohy,

[...] te reakcje są weryfikowane i uznane za trafne, jeśli ich rezultaty przynoszą grupie zadowolenie. Aby utrzymać wysoki poziom satysfakcji z tego, jak grupa reaguje na reakcje, patrzy ona przez pryzmat zwyczaju wspólnego, przekazywanego innym, zwłaszcza nowym członkom, bo „tak tutaj się robi”. Tak więc założenia następujące w kulturze organizacji obejmują wiedzę, emocję, przekonania i postawy (Tuohy 2002: 24).

Kulturę szkoły konstytuuje dynamiczna wymiana między teoretyczną wiedzą pedagogiczną, zintegrowaną z wiedzą filozoficzną, psychologiczną, socjologiczną i innymi dziedzinami związanymi z realizacją funkcji szkoły, a wiedzą praktyczną, między tym, co idealne a osiągalne, między strategicznym planowaniem a strategiami realizacji (Tuohy 2002: 24). Kultura środowiska, w którym szkoła funkcjonuje, i płynące $z$ niej wyzwania oraz zadania stawiane przez władze oświatowe, warunkują nowe cele oraz autoocenę możliwości i dotychczasowych strategii działania, czyli odpowiedź na pytania: Na ile szkoła jest przygotowana, by sprostać nowym zadaniom? W jakim kierunku należy zmierzać i kiedy należy rozpocząć doskonalenie dotychczasowych rozwiązań w perspektywie adaptacji do zewnętrznych potrzeb złączonych z procesem wewnętrznej integracji? Odpowiedzi na te pytania zakładają nową konfigurację znaczeń wewnątrz szkoły. Dydaktyka zaangażowana ma za zadanie ukazać drogę wiodącą do budowania, rozwijania kultury szkoły na bazie 
tych dwóch procesów. Pojawia się cel, jakim jest poszukiwanie nowych sposobów budowania rytuałów, pełnienia ról, przestrzegania norm w perspektywie integralnego rozwoju osoby, ucznia i twórczego rozwoju nauczyciela, ustalania podstawy aksjologicznej procesu edukacyjno-wychowawczo-dydaktycznego oraz jego założeń (Tuohy 2002: 24).

Drugim zadaniem dydaktyki zaangażowanej jest przygotowanie studentów do badania kultury szkoły, a więc jej wytworów, założeń i wartości. Trzecim zaś celem jest wspomaganie studentów w projektowaniu kultury szkoły na bazie doświadczanego wglądu w kulturę szkoły ukończonej w cyklu kształcenia - na różnych etapach edukacji. W tym względzie na uwagę zasługują takie kwestie jak: związki szkoły z otoczeniem, natura ludzkich działań, ludzka natura, związki między ludźmi (Tuohy 2002: 25).

Każda szkoła funkcjonuje w określonym środowisku społeczno-kulturowym i przyrodniczym, które ma swoje oczekiwania oraz stanowi szansę rozwoju lub też jest dla niego przeszkodą.

Związki szkoły ze środowiskiem otwierają przestrzeń do kreowania tożsamości postkonwencjonalnej, a przez to do budowania znaczącej pozycji nauczyciela w środowisku szkoły, jego autorytetu, stwarzają szanse do emancypacji rozumianej jako proces „świadomego konstruowania własnej tożsamości przez wyodrębnianie jej istotnych elementów oraz działanie nakierowane na ich osiaganie" (Tuohy 2002: 25). Jest to „proces świadomego odrzucenia stereotypów i mitów, pokonywania utrudnień wywołanych aktywnością ludzką i siłami natury" (Tuohy 2002: 33).

Ta prorozwojowa perspektywa związków szkoły z otoczeniem wpływa na założenia o naturze ludzkich działań. Dotyczy budowania aksjologicznej podstawy procesu wychowawczo-dydaktycznego prowadzącego do integralnego rozwoju, pełni człowieczeństwa oraz postaw warunkujących rozwój własny i środowiska, w którym uczeń żyje i funkcjonuje. Ważną kwestią staje się wspomaganie uczniów w urzeczywistnianiu własnej, lecz właściwej hierarchii wartości, kształtowaniu aktywnej postawy wobec wartości, rozwijaniu aktywności o wymiernych efektach, wykształceniu krytycznego stosunku wobec własnej sytuacji/położenia tu i teraz i w przyszłości, we wzmacnianiu poczucia własnej wartości i wiary w siebie, budowaniu ambitnych celów i planów życiowych, udoskonaleniu umiejętności 
przywódczych, interpersonalnych, społecznych. Ta sylwetka ucznia zobowiązuje nauczyciela do określonej postawy, do zmiany roli z nauczyciela przekazującego wiedzę na rolę przewodnika, animatora, osobę towarzyszącą na ścieżkach rozwoju fizycznego, poznawczego, społeczno-moralnego, kulturowego, duchowego. Te postawy i orientacje winny się stać celami akademickiego kształcenia przyszłych nauczycieli. Dydaktyka zaangażowana w kształceniu przyszłych nauczycieli ma ukazać, w jaki sposób można formować taką właśnie sylwetkę ucznia, jakie sytuacje wychowawcze należy stworzyć, w jaki sposób oceniać i nagradzać uczniów, a później nauczycieli, by temu zadaniu sprostać.

W związku z powyższym, studentom można zadać następujące pytania: $\mathrm{W}$ jaki sposób wspomagać uczniów w odkrywaniu prawdy obiektywnej i umiłowaniu tej prawdy? W jaki sposób konstruować doświadczenia uczniów będące źródłem wiedzy o nich samych, o otaczającej ich rzeczywistości? W jaki sposób rozwijać zdolności poznawcze, uzdolnienia i zainteresowania oraz twórcze podejście do problemów? W jaki sposób wspomagać uczniów w pracy samokształceniowej i wyzwalać potrzebę uczenia się przez całe życie? W jaki sposób wspomagać wychowanków w formułowaniu celów i planów życiowych oraz wyposażać ich w predyspozycje do ich osiągania w perspektywie integralnego rozwoju?

Punktem wyjścia w budowaniu kultury szkoły jest koncepcja ludzkiej natury oraz pogląd, że człowiek jest z natury dobry, zły lub „taki sobie” (Tuohy 2002: 33). Kluczowe staje się przyjęcie konkretnej koncepcji człowieka. Istotne stają się więc pytania: Kim jestem? Jakim człowiekiem mogę się stawać? Jakim człowiekiem powinienem się stawać? Odpowiedzi na te pytania nie mogą prowadzić do redukcji wartości człowieka i jego człowieczeństwa.

Kultura szkoły jest zjawiskiem złożonym, dynamicznym, przybierającym różne kształty rozwojowe. W powyższym kontekście zakres aktywności nauczyciela akademickiego i studenta przedstawia poniższy schemat. 
Schemat nr 2. Zakres aktywności nauczyciela akademickiego i studenta - w aspekcie kultury szkoły

\begin{tabular}{|c|c|c|}
\hline Przestrzeń & Nauczyciel akademicki & Student \\
\hline Szkoła i jej kultura & $\begin{array}{l}\text { - Podejmowanie badań na- } \\
\text { ukowych nad kultura szkoły } \\
\text { w ujęciu historycznym, współ- } \\
\text { cześnie i w przyszłościowej } \\
\text { perspektywie. } \\
\text { - Prowadzenie badań w dzia- } \\
\text { łaniu nad rozwojem kultury } \\
\text { szkoły. } \\
\text { - Właczanie w proces badaw- } \\
\text { czy studentów. }\end{array}$ & $\begin{array}{l}\text { - Projektowanie szkoły } \\
\text { autorskiej. } \\
\text { - Projektowanie klasy autorskiej. } \\
\text { - Projektowanie rozwiqzywa- } \\
\text { nia złożonych problemów } \\
\text { nauczania, wychowania, } \\
\text { opieki w perspektywie rozwoju } \\
\text { szkoły. } \\
\text { - Projektowanie własnego roz- } \\
\text { woju zawodowego. } \\
\text { - Właczanie się w proces } \\
\text { badawczy nauczyciela } \\
\text { akademickiego. }\end{array}$ \\
\hline
\end{tabular}

Źródło: Opracowanie własne.

\section{Podsumowanie}

Teoretyczną podstawę dydaktyki zaangażowanej stanowi integracja teorii: 1) dydaktyki ogólnej, 2) dydaktyki akademickiej/szkoły wyższej, 3) pedagogiki personalistycznej, 4) integralnego rozwoju osoby, 5) społecznego uczenia się, 6) kultury szkoły, 7) tożsamości człowieka i szkoły jako organizacji.

W centrum dydaktyki zaangażowanej znajduje się osoba nauczyciela akademickiego i studenta oraz ich zintegrowane aktywności zorientowane na: 1) własny integralny rozwój, strukturę zadań wzajemnie ukierunkowanych na rozwój kompetencji w aspekcie twórczej pracy, 2) orientacja aksjologiczna w stronę urzeczywistniania własnej, lecz właściwej hierarchii wartości, 3) dyskurs, dialog, rozmowa, troska i przyjacielskie ustosunkowanie się, 4) wspólpraca, szczególnie $\mathrm{w}$ aspekcie budowania procesu badawczego.

W aspekcie dydaktycznym podstawową strategią jest edukacja przez projekty indywidualne, grupowe i projekty wspólnie realizowane $z$ nauczycielem akademickim. Chodzi głównie o projekty badawcze oraz projekty odnoszące się do przyszłej pracy zawodowej, zwłaszcza budowania kultury szkoły, którą można by określić jako szkołę twórczą. 
Dydaktyka zaangażowana wymaga szczegółowych badań o charakterze teoretycznym i empirycznym. Powinny one koncentrować się na jej naukowych podstawach, ze wskazaniem szczegółowej egzemplifikacji w praktyce oraz na osobowościowych i społeczno-kulturowych uwarunkowaniach realizacji w kształceniu przyszłych nauczycieli.

\section{Bibliografia}

Adamski F. (2005). Wprowadzenie. Personalizm - filozoficzny nurt myślenia ocztowieku i wychowaniu, [w:]: F. Adamski (red. ), Wychowanie personalistyczne. Wybór tekstórw, Kraków: Wydawnictwo WAM, s. 9-15.

Bereźnicki F. (2001). Dydaktyka kształcenia, Kraków: Oficyna Wydawnicza „Impuls".

Červinková H., Gołębniak B.D. (2010). W poszukiwaniu emancypacyjno-transformacyjnego wymiaru badan pedagogicznych $i$ antropologicznych, [w:] H. Červniková, B.D. Gołębniak (red.), Badania w dziataniu. Pedagogika i antropologia zaangażowane, Wrocław: Wydawnictwo Naukowe Dolnośląskiej Szkoły Wyższej, s. VII-XVII.

Chałas K. (2019). Dydaktyka akademicka w uniwersytecie katolickim, t. 1: Dydaktyka zaangażowana - z doświadczeń Katedry Dydaktyki i Edukacji Szkolnej KUL, Lublin: Wydawnictwo KUL.

Cybal-Michalska A. (2018). Rozwiązyzuanie problemórw natury tożsamościowej w świecie różnorodności i wielości możlizwości, [w:] M. Czerepaniak, J. Madalińska-Michalak, B. Śliwerski (red.), Ku życiu wartościowemu. Idee-koncepcje-praktyki, t. 1: Idee - koncepcje, Kraków: Oficyna Wydawnicza „Impuls”, s. 125-146.

Krąpiec M. (2005). Cztowiek - dramat natury i osoby, [w:] F. Adamski (red.), Wychowanie personalistyczne. Wybór tekstórw, Kraków: Wydawnictwo WAM, s. 23-40.

Tuohy D. (2002). Dusza szkoty. O tym, co sprzyja zmianie i rozwojowi, przeł. K. Kruszewski, Warszawa: Wydawnictwo Naukowe PWN.

Witkowski L. (2010). Tożsamość i zmiana. Epistemologia i rozwojowe profile w edukacji, Wrocław: Wydawnictwo Naukowe Dolnośląskiej Szkoły Wyższej.

\section{ADRES DO KORESPONDENCJI}

Prof. dr hab. Krystyna Chałas

Katolicki Uniwersytet Lubelski Jana Pawła II

Wydział Nauk Społecznych

Instytut Pedagogiki

e-mail: kryschal@kul.lublin.pl 